\title{
MGA wt Allele
}

National Cancer Institute

\section{Source}

National Cancer Institute. MGA wt Allele. NCI Thesaurus. Code C115317.

Human MGA wild-type allele is located in the vicinity of $15 q 14$ and is approximately $149 \mathrm{~kb}$ in length. This allele, which encodes MAX gene-associated protein, is involved in the regulation of MYC and MAX-dependent gene expression. 